\title{
Thoughts on Ancient Metallurgy and Mining Among the Brigantes and in Some Other Parts of Britain, Suggested by a Page of Pliny's Natural History
}

John Phillips M.A., LL.D., F.R.S.

To cite this article: John Phillips M.A., LL.D., F.R.S. (1859) Thoughts on Ancient Metallurgy and Mining Among the Brigantes and in Some Other Parts of Britain, Suggested by a Page of Pliny's Natural History, Archaeological Journal, 16:1, 7-21, DOI: 10.1080/00665983.1859.10851103

To link to this article: http://dx.doi.org/10.1080/00665983.1859.10851103

曲 Published online: 10 Jul 2014.

Submit your article to this journal $匚$

View related articles $\sqsubset$ 
THOUGHTS ON ANCIENT METALLURGY AND MINING AMONG THE BRIGANTES AND IN SOME OTHER PARTS OF BRITAIN, SUGGESTED BY A PAGE OF PLINY'S NATURAL HISTORY.

BY JOHN PHILIIPS, M.A., LL.D., F.R.S.,

President of the Geological Society, Reader in Geology in the University of Oxford.

To one who meditates on the progress of natural knowledge, the difficulty of penetrating to a true estimate of its condition in past ages often appears unconquerable, except in cases which admit of the interpretation of ancient results by modern laws and theories. Once in firm possession of such laws, we enclose the old phenomena, so to speak, in a field to which are only such and such possible avenues, and thus can sometimes declare the very mode by which the alchymist was led to his golden error, and the Chaldæan shepherds were guided to brighter truths. Without this principle of interpretation many almost modern writers, nay authors of this very century, can sometimes not be understood. The laws of modern Geology and Zoology, for such there are and well-founded too, are as much required to put a true construction on some of the writings of Lister and Linnæus, as the methods of Ray, Linnæus, and Cuvier are required for the just estimation of Aristotle. We shall probably find the darkest pages of antiquity to be precisely those which refer to subjects where our own knowledge is least clear, least collected into laws of phenomena, and most removed from laws of causation. Ought we not, before declaiming on the ignorance of the ancients, to be careful to make allowance for the differences of form in which knowledge presents itself at different periods, as well as for the incompleteness of their records, and the imperfection of our interpretations?

Pliny's Natural History appears to me to be precisely in the position of difficulty which has been already alluded to. Its vastness, variety, and seeming disorder, may well deter the most comprehensive master of modern science from duly weighing its mass, or even measuring its surface; and the evident incompleteness and almost haphazard character of 
its chapters are apt to disgust the student of special branches of science and art. Yet, probably, if for each important branch of human knowledge handled by Pliny, a special editor were set to work, well versed in the philosophy of his subject, Pliny would take a higher degree on examination, and the history of human knowledge be amended.

From the thirty-seven books of diffuse and erudite learning the genuine work of Pliny the Elder, let us fix on the part which treats of the nature of metals, and, passing over his lamentations on the useless excess of gold and silver -which may be recommended to the Chancellor of the Exchequer-his accounts of the uses and properties of gold, electrum, ${ }^{1}$ chrysocolla, silver, quicksilver, stibium, scoria argenti, spuma argenti, minium, cinnabar, brass, cadmium, iron, and many compounds of metals, let us pause at the 16 th chapter of the 34 th book, which treats of the metals of lead, white and black.

He first treats of the most precious of these, the white, called by the Greeks cassiteros, and fabulously declared to be sought for in Isles of the Atlantic, to which it is brought in wicker vessels covered with leather, ("vitilibus navigiis corio circumsutis"). But now it is ascertained to be indigenous in Lusitania and Gallicia, in sandy surface soil, of a black colour, and only distinguished by its weight. Small pebbles (of the ore) also occur, principally in dried beds of streams. The miners ("metallici") wash these sands, and what subsides they melt in furnaces.

It is also found with the gold ores ("aurariis metallis") which are called stream works (" elutia"), the stream of water washing out ("eluente") black pebbles a little varied with white, and of the same weight as the gold. On this account, in the vessels in which the gold is collected, these pebbles remain with it; afterwards they are separated in the chimneys " "caminis separantur"), and being melted are resolved into "plumbum album."

In Gallicia "plumbum nigrum" is not made, because the adjoining Cantabria (Asturias) so much abounds in that metal.

Not out of white plumbum as out of the black can silver be extracted.

1 Gold, with one-fifth of silver.

- What distinctive meuning should be attached to fornaces and camini is uncer- taiv. It seems that the camini may in. dicate if not what we call chimneys, ut least cavities in or about the furnace. 
To solder together (pieces of) "plumbum nigrum" is impracticable without (the use of) white plumbum, nor the white to the black, without the addition of oil. Nor can (pieces of) white plumbum be soldered together without the aid of the black metal.

That (plumbum) album was in esteem during the Trojan time Homer is witness, who calls it cassiteron.

Of "plumbum nigrum" the source is double : either it comes from its own vein, without admixture, or grows with silver, and is melted while mixed with that metal. The part which is first liquid is called "stannum;"3 that which flows next is silver; that which remains in the furnace "galena," which is the third portion of the vein (or ore). This being again melted ${ }^{5}$ yields "plumbum nigrum," (the other) two parts (of the ore) being deducted.

This chapter is a text on which a thirty-eighth Book of Natural History might be written, embracing the

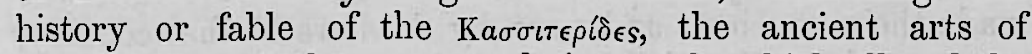
metallurgy, and the eager trade in metals which allured the Phœnician sailors on the Atlantic, and led the Roman armies to Britain.

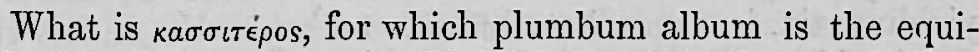
valent? what is stannum, obtained from mixed ores of silver and lead? what is galena, elsewhere called molybdiena (cap. 18). We need not ask what is plumbum nigrum, for by that is clearly designated lead.

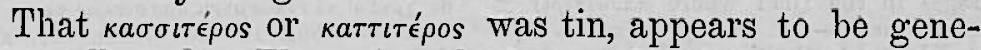
rally allowed. The mineralogists and miners who know the mode of occurrence and character of tin ore, will have no doubt that plumbum album of Pliny is tin, and that author twice positively and expressly identifies this with cassiteros. $^{6}$

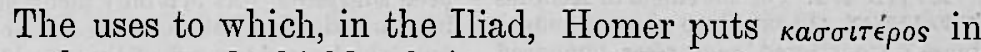
the thorax and shield of Agamemnon, in the shield and greaves of Achilles, in the brazen thorax of Asteropæus, and in the chariot of Tydides, are such as imply easy fusibility

3 Analogous to this is the process of separating silvery lead from mere lead, invented by Mr. H. L. Pattison.

4 Pliny, Nat. Hist., lib. xxxiv, cap. 18. "Est et molybdæna, quam alibi galenam vocavimus, plumbi et argenti vena communis."

5 At the present day wo should per- form this melting of the residual galena, in the slag hearth, with a fux.

6 Supposing the word to be Greek, Eustathius gires for its roots kavors $^{\circ}$ and $\tau \in \rho \in \omega-$ as if easily attacked by fire; $\kappa \alpha \sigma \sigma \alpha$, meretrio, has also been suggested, as if it was false silver. 
and ductility, and indicate that the metal was highly valued and almost precious.

In the Odyssey, full as it is of pictures of regal and

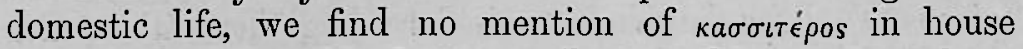
ormament, while gold, electrum, silver, and brass abound.

Virgil puts no tin into the arms of Aneas; perhaps the metal was then of too vulgar use, employed too much by tinkers, to be fit for a heroic shield. Electrum is substituted, and iron is the staple article in the Vulcanian workshop, as

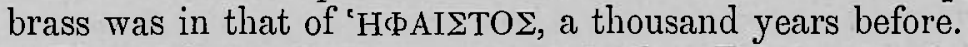

The picture of the great artist, the Tubal-cain of the West, the cunning worker in metal, who melted, alloyed, inlaid, carved, and polished his work, whose multiplied bellows breathed at the will of the god, softly or fiercely, whose brass was hardened to wound or tempered to bend, is perfect, and might be paralleled on a small scale till within a few hundred years in the famous smiths of Wales, who made their own iron, and were by the laws of that country, as renewed by Howel Dda, allowed to sit near the priest of the household in the king's presence.

Why Pliny treats as a fable the story of the Cassiterides yielding tin, is somewhat difficult to say. He classes the Cassiterides with Hispania ("ex adverso sunt insulæ,-Cassiterides dictæ Græcis, a fertilitate plumbi "), ${ }^{9}$ and speaks of

7 The following are the principal pas.

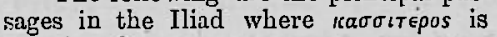
mentioned :-

XI. 24. In the thorax of Agamemnon

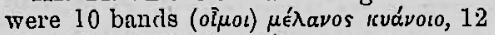

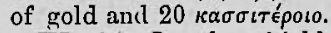

XI. 34. In the shield of Agamem. non were twenty white bosses $(o \mu \phi \alpha \lambda o l)$ of tin, and in the middle one of black (rvaivos).

XVIII. 474. For the shield of Achilles

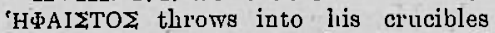
brass unconquered, $\kappa \alpha \sigma \sigma i \tau e \rho o s$, honoured gold, and silver. 564. He pours the tin round the horder.

XVIII. 574. The cows with uplifted heads were fubricated of gold and tin:

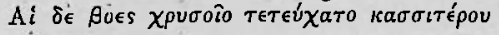
$\tau \epsilon$.

XVIII. 612. The greaves of Achilles

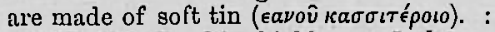

$\mathrm{XX}, 270$. In this shield were 5 plates the 2 exterior ones brass; within theso

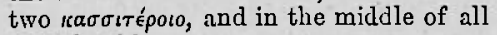
one of gold.

XXIII. 503. The chariot of Diomedes was adorned with gold, and tin : appara

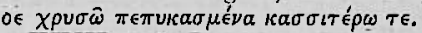

XXIII. 561. In the brazen thorax of Asteropæus the border was of glittering

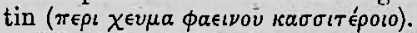

What is in tho Iliad and Odyssey called suavos, and is apparently ar muchvalued substance, is difficult to be identified. From its colour, Lapis Lazuli, Turquoise, and Carbonate of Copper have been suggested. As it is only mentioned in connection with the arms of Agamemnon, which were the gift of Cinjras, king of Cyprus, the latier mineral may be thought to have the best title, especially if, as at Chessy, it occurs blue in Cyprus. Millin, indeed (Minéralogie Homérique, p. 160), supposes кuavos to be another name for tin ; but surely with little reason. It was used for ornament in the palace of Alcinous.-Odyssey, vii. 87.

8 Ancient Laws and Institutes of Wales, vol. i. pp. 11, 73. The place of the smith of the court is fixed on the end of the bench, before the priest.

0 Pling, Nat. Hist. lib. iv. cap. 22. 
Mictis, on the authority of 'Timæus the historian, as six days' sail from Britain, and as yielding "candidum plumbum." If the Cassiterides are the Ocrynian Promontory and the Scilly Isles, from which, as recorded by Strabo, the Phœni-

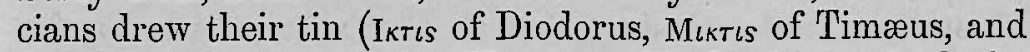
Ovink tin was carried through France to Marseilles), we may suppose that in the early period, the only route for the tin of Cornwall to the Mediterranean was by sea to the western parts of Spain ; but that in the latter period the track by land through Gaul to Massilia was preferred, and the old trade had become a tradition which Pliny chose not to adopt from Strabo, who is never quoted on this subject by the author of the Historia Naturalis, but may be obliquely and slightingly alluded to. Whether tin occurs at all in any part of the Spanish Peninsula can hardly be doubtful after the assertion of Pliny. He had been procurator in Spain, and by his intimacy with Vespasian, ${ }^{2}$ must be supposed in position to learn much of Britain, from the despatches of Petilius Cerealis, Ostorius Scapula, and Agricola. But he was suffocated by the fumes of Vesuvius, in 79 , one year after the appointment of Agricola to Britain; and for the greater part of his literary life, Britain was a scene of neverending war and confusion. Besides this the Cornish Promontory appears to have been at no time much occupied by Roman stations, or traversed by roads, and it may be thought to have had then, as afterwards in Saxon and Norman times, a history and commerce quite distinct from and little known to the Belgic settlers in Albion. He might be mistaken respecting Britain, of which perhaps he could know only Albion; but his positive assurance of the occurrence of tin in Spain is confirmed by a passage in Bowles's Natural History of Spain, and, as I hear from Mr. Kenrick, by a later German writer, Hopfensach; it occurs, in fact, according to one of our best books of Mineralogy, in beds in the mica schist of Gallicia. ${ }^{3}$. Oxide of tin has been found, besides, on both sides of the Erzgebirge in granite; at Puy de Vignes, the department of Haute Vienne, also in granite; in Wicklow (granite); on the east coast of Sumatra, in Siam and Pegu,

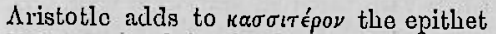
$\mathrm{K} \in \lambda \tau$ เ $\mathrm{k}$, implying its local origin in the west of Europe.
1 Pliny, Nat. Hist., lib. iv., cap. 16.

2 Vespasian became Emperor, 4.J. 69.

3 See W. Phillips' Mineralogy, 1823. 
in Banca and Malacca. It has been found in Mexico, Chili, and Greenland, and mixed with other matters in Finland and Sweden.

Upon the whole, the case is probably thus : it is the old Phœnician trade, destroyed with Carthage, which Strabo describes, and Publius Crassus went to explore in the

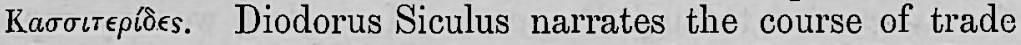
in the days of Augustus from Ictis, when Gaul offered an easy route to the Mediterranean ; but one hundred years of war and commotion interrupted this trade of Cornwall with the East, and Pliny was suspicious of the fables of Greece, and knew that tin was obtained in Spain. Notwithstanding this fact, it appears that Cornwall and the Asiatic Isles have been the principal, almost the only sources of the tin of the ancient world, that of Zinnwald, in Wirtemberg, being quite unknown till a much later date.

Stannum is evidently an alloy of an argentine or tin-like aspect, a variable pewter, a metal more easily melted than copper, for the lining of which it was much used in Pliny's days, to obviate the danger of cupreous solutions. This process we now call tinning, and stannum ${ }^{4}$ with its variable meanings is perhaps the common parent of the French tetain, meaning as often pewter as tin, and of the German Zinn, which like "tin" in the English workshops, is used sometimes for pewter when lining vessels, and solder when covering surfaces which are to be joined. Our German silver, Britannia metal, \&c., belong to this class. The process of illination with stannum must have been well executed to justify the exclamation of Pliny, that it did not augment the weight of the vessel to which it was applied. The Brundisian specula made of it yielded to silver, indeed, at last; but they are declared to have been of admirable efficiency.

Stannum, then, is an alloy of tin with lead, tin with brass, tin with antimony, lead with silver, or other variable mixtures of metals often associated in nature.

Pliny mentions adulterate or alloyed kinds of stannum, composed of one part white brass to three parts of candidum

1 Pliny's notices of stannum are fiequent. See Hist. Nat. with the notes by Harduiu, vol. ii. 429,$22 ; 528,7$; 530, 30, 31, \&c., edit. Puris, 1827, 10 vols. 8 vo.
Stanno et ære mixtis, 627,11 -illitun æneis vasis saporem gratiorem facit, 669 , 14-discerui vix possit ab argento, 669 , 26 -æramentis jungitur, 669, 11. 
plumbum ; of equal weights of candidum and nigrum (which is called argentarium); of two parts of nigrum and one of candidum (called tertiarium); with this last lead pipes were soldered. ${ }^{5}$ Fraudulent dealers add to the tertiarium equal parts of album, call it argentarium, and with it plate or line other metals.

He gives the prices of these compounds and those of pure album and nigrum, the former twenty, the latter seven denarii for one hundred pounds.

Plumbum album, he says, is rather of an arid nature ; the nigrum is entirely humid ; therefore the white is of no use unless it be mixed with another metal. Silver cannot be leaded (lined) with it, it will be melted first. It is affirmed that if there be too little nigrum mixed with the album, the silver will be corroded by it. Album is melted into brasswork (inlaid, an invention of Gaul), so that it can hardly be known from silver-these works are called incoctilia (silvered). He then speaks of the application of this invention to the trappings of horses, and carriages, and other curious productions of Alesia and the Bituriges ; a subject which my friend Mr. Kenrick has handled with his usual felicity. ${ }^{6}$

One of Pliny's sentences is remarkable as narrating a class experiment fit for a chemical school: "Plumbi albi experimentum in charta est, ut liquefactum pondere videatur, non calore, rupisse." The meaning seems to be, that the metal is fluid at so moderate a heat as when fused to break by its weight, not burn by its heat, the charta on which it is poured. Tin melts at $440^{\circ}-442^{\circ}$; lead, at $612^{\circ}$.

What follows is a very important passage : "India neque æs neque plumbum labet, gemmisque suis ac margaritis hoc permutat."

May we be justified by this sentence in refusing to credit the supposition that tin (plumbum album) was brought overland or by other routes from the Asiatic Isles and shores towards Western Europe? If so, Cornwall chiefly, if not wholly, supplied the tin which entered so many ways into the comforts and necessities, during peace and war, of all the nations surrounding the Mediterranean and Euxine, Baltic

\footnotetext{
5 "Hoc fistule solidantur." This is the solder of our tinmen.

- See a memoir by the Rer. Jobn

YOL. XYI.
}

Kenrick, Trans. of Yorkshire Phil. So ciety, 1848 , p. 52 . 
and German Ocean ; in fact, the world, as distinctly known to the Roman geographers.

Let us now inquire into the means whereby the ancient people reduced the metals which they were so earnest in seeking across mountains and oceans at the point of the sword. To confine the inquiry within reasonable limits, we shall speak chiefly of tin and lead, the only metallic products, as it appears, which were regarded by the ancients as abundant in Britain. Iron is mentioned by Cresar as of limited occurrence: " in maritumis ferrum, sed ejus exigua est copia."

Gold, the most widely if not most abundantly distributed metal, found near the surface of the earth in a pure and malleable state, easily fused, uninjured by fusion, was probably the metallic substance on which the earliest processes of fire were tried, and they could not be tried unsuccessfully.

Tin, the ore of which has been found at the surface in many situations with auriferous sand and gravel, cannot have been long unknown to the gold-finders of the East and the West. Some one of the many accidents which may, or rather must, have accompanied the melting of gold would disclose the nature of the accompanying white metal, whose brilliancy, ductility, and very easy fusibility would soon give it value.

The melting of Tin Ore is, however, a step in advance of the fusion of Native Gold. The gold was fused in a crucible $^{7}$ made of white clay, ${ }^{8}$ which only could stand the heat and the chemical actions which that generated; but tin ore would in this way of operation prove totally infusible. It must be exposed at once to heat and a free carbonaceous element. The easiest way of managing this is to try it on the open hearth. Perhaps some accidental fire in the halfburied bivouacs of the Damnonii may have yielded the precious secret. As to the fuel, we are told that pine woods were best for brass and iron, ${ }^{9}$ but the Egyptian papyrus was also used, and straw was the approved fuel for gold. In the metalliferous country of Cornwall and Devon, peat is plentiful, and the charter of King John, in the year 1201, grants to the miners the privilege of digging tin, and turves to melt the

7 Pliny, Nat. Hist., lib. iv. cap. 33, p. 617 , ed. Harduin.

s Such as now called Cornish clay, for example.

' Pliny, Nat. Hist. lib. iv. cap. 33, p. 621 . 
tin, anywhere in the moors, and in the fees of Bishops, Abbots, and Earls, in those counties, as they had been used and accustomed. This charter was confirmed by Edward I. Richard II. and Henry IV.'

These and other singular privileges extending as far as the lands on which the Crown claimed rights, are long anterior to the other rights of property in Cornwall, Mendip, Derbyshire, and the Forest of Dean, and go far to justify the supposition of our modern mining laws being a relic of Roman, or perhaps of earlier than Roman times.

As the bellows was known at least a thousand years before Pliny, we have here all the materials for a successful tinsmelter's hearth. If the smelting work was on waste land, and a little sunk in the ground, we recognise the old 'Bole' or 'Bloomery' of Derbyshire, now only a traditional furnace, but anciently the only one for the lead and iron of that country.

Pure tin once obtained, there must intervene a long series of trials and errors before its effect in combination with lead, brass, silver, \&c., could be known ; before the mode of conquering the tendency to rust in the act of soldering could be discovered (oil being in this respect as valuable to the tinner as artificial Chrysocolla was to the jeweller and goldsmith). ${ }^{2}$ From all this it follows that the smelting of tin might be, and probably was, performed by the inhabitants of the Cornish Peninsula. This art they may have brought from the far East; Phœnicians may have taught it them; but all the accounts of the ancient tin trade represent the metal, and not the ore, as being carried away from the Cassiterides. Diodorus mentions the weight and cubical form of the tin in

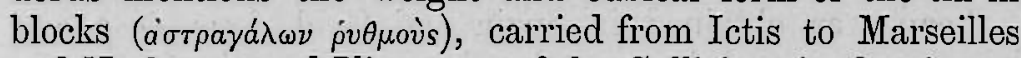
and Narbonne, and Pliny says of the Gallician tin that it was melted on the spot.

Did the Cornish or Gallician miners make bronze? For this is generally the compound indicated by the Roman aris metalla, though it is undoubted that they also knew of, and distinguished zinc brass. There is, I believe, no instance of a single bit of pure tin or pure copper being found with the numerous celts, which occur in so many parts of England ;

1 Printed in the Appendix to $\mathrm{De}$ Beclec's Report on the Geology of Cornwall, p. 625 .
2 Pling, Nat. Hist., lib. iv. cap. 33, p. 621, ed. Harduin.

${ }^{3} \Lambda$ celt of the simplest form, the axe- 
nor is any other proof given that the direct union of tin and copper was effected by the natives of Britain. Copper is so abundant in Cornwall that it might tempt us to the other hypothesis; but this copper is a sulphuret; it is found united to the sulphuret of iron, in deep veins, and in a matrix of quartz; and these are things which render the production of pure copper one of the most refined operations in smelting. Cæsar tells us the brass used by the natives of Britain was imported ("ære utuntur importato"). Probably Cyprus,colonised by the Phœnicians, to which old authors refer as the original source of brass-Cyprus with its ancient copper mines (Tamassus), and which has given its name to the metal, might be one of the points from which bronze radiated over the Grecian, Roman, and Barbarian world. It was from Cinyras, the king of Cyprus, that Agamemnon received his splendid breastplate with twenty plates of tin, and its liberal additions of Turquoise, Lazulite, or rather Malachite, obtained perhaps from the soil of the Island. ${ }^{4}$

The works of "Hфaioros, the Crawshay of antiquity, may have been fixed in Lemnos on account of some volcanic appearances there; but the tradition shows at least that the various operations of refined metallurgy were not strangers to the Islands of the Mediterranean ; and the uniformity of design and composition in the ancient celts, chisels, $\mu a \dot{\kappa} \in \lambda \lambda a$, and instruments of war, implies a common, and that not a barbarous origin. The perfection, and variety, and great proportions of the brass work executed in the Grecian states and colonies, may also be regarded as indicating the local seat of the early as well as the later art of working in bronze.

Lead was obtained in Spain and Gaul, from deep and laborious mines $;$ but so abundantly, near the surface, in Britain, as to suggest a law for preventing more than a limited production-a Brigantian law of vend. ("Nigro plumbo ad fistulas laminasque utimur, laboriosius in Hispania eruto, totasque per Gallias, sed in Britannia summo terræ corio adeo large, ut lex dicatur, ne plus certo modo fiat." Lib. 34, cap. 17. p. 644). The Romans employed lead in

head without socket or stop-ridge, is preserved in the Duke of Northumberland's Museum at Alnwick Castle. The metal of which it is formed is of a red colour and resembles copper, but no test has been used to ascertain the fact of its being of that metal. It was found in draining a moss near Percy's Leap, Northumberland.

${ }^{4}$ Pliuy, ut supra, p. $633 .{ }^{5}$ Ib., p. 669. 
pipes (fistulæ) and sheets, which were soldered with alloys, as already mentioned. This lead was previously refined, and its silver removed; the silver, indeed, being often the object of the enterprise. How earnestly silver was soughthow well the mining operations were carried on by the 'old men, ${ }^{\prime}$ appears from the notice of the Carthaginian mines in Spain, the pits and levels driven by Hannibal being mentioned as in wonderful preservation by Pliny. The same may be said of at least one set of mining works of Roman date, in the extreme parts of South Wales, viz. the Gogofau mines near Llandovery, Caermarthenshire, where gold was extracted with much labour from broken and pounded quartz, of which enormous mounds remain. The adit still exists, and was entered by the late Sir H. T. De la Beche, who found in it a specimen of native gold. In the vicinity, tradition indicates a Roman settlement ; and a chain of gold and other ornaments were found, some of which are now possessed by the family of Johnes of Abercothi.?

The districts in Britain, where lead veins coming to the surface in abundance might justify the praises of Pliny, are in the South, Mendip; in the West, Flintshire; in the North, Derbyshire, Yorkshire, and Cumberland, that is to say, the Brigantian Territory; and it is to this last district that the descriptions apply most correctly. Lead cast in Roman moulds, 'pigs' in fact of the age of Hadrian and other Emperors, have been found in Derbyshire, Staffordshire, Cheshire, Shropshire, Nottinghamshire, Yorkshire, Somersetshire, Hampshire, and Sussex. But few ancient mining instruments have ever been found in the lead-bearing districts of Britain, ${ }^{8}$ and I am strongly of opinion that much of the lead ore was collected from the surface by aid of water, artificially directed. The process, in fact, is described by

6 This term is employed by the miners of the north of England. When they meet with the fodinn of earlier days, they say they come upon ' $t$ ' auld man'-perhaps auld in the days of the Anglians.

7 An account of these discoveries was communicated to the Archaeological Institute by Mr. John Johnes, of Dolancothi, and it may be seen in this Journal vol. vii. p. 173. There part of the gold chain is figured. See Sir R. I. Murchison's Remarks on Gogofau, Sil. Syst. pp. 367,368 , and Mr. Warrington Smith's notices in the Memoirs of the Geological
Survey, p. 481.

8 Sir R. I. Murchison mentions Roman mining utensils at Shelve in Shropshire, Silur. Syst. p. 279. In the Museum of the Institute at the Annual Meeting in Shrewsbury, 1855, a pig of lead bearing the name of Hadrian was exhibited by the Rev. F. More, of Linley, with two mining spades of cleft oak, stated to have been found in the Gravels Mine at Shelve. They were figured in a notice of Roman metallurgy in Shropshire, by Mr. Thomas Wright. - Illustrated London News, Oct. 4, 1856. See also the Appendix to this memoir. 
Pliny, in terms so exactly applicable to the modern ' hushes' of Swaledale, that no doubt can remain of this custom, which is now esteemed rude and semi-barbarous, being of Roman or earlier date in Britain.

As thus from Roman or earlier times our lead mining derives its 'hush,' its levels, and shafts, implements for washing and other processes of the workmen, and the forms, weights, and marks of its melted metal, we may easily admit a similar origin for the melting processes. Lead mostly occurs in the sulphuret, which offers no particular difficulty in the fire. By cautious roasting; its excess of sulphur may be removed, and the subsequent melting with charcoal or a flux be facilitated. Indeed, without roasting and without flux, in many cases the lead will flow out of the ore, if placed among flaming wood or peat, and subjected to a sufficient stream of air.

But the use of fluxes could not long remain unknown in the limestone districts of Northumbria, or amid the fluoric veins of Derbyshire, limestone and fluor being to this day valuable aids in the furnace. Peat was the fuel in Cornwall, and still is in Yorkshire, and perhaps the Roman smelters did really erect their furnaces on waste ground and heaths at Dacre and Matlock, far from the mines of Greenhow and Youlgreave, even as is done at present with the cupolas of Lee and Langley mills.

The uses of crucibles (xóavor), bellows, cavities of some

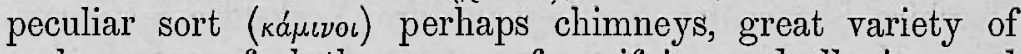
carbonaceous fuel, the power of purifying and alloying, and knowledge of the properties of alloys, appear quite conspicuous among the ancient arts.

The inscriptions ${ }^{9}$ on these masses of lead, are in the same general form as the 'marks' of the different mines now in work, and which, no doubt, are their literal and lineal descendants. Thus the Ald or Auld Gang mine of Swaledale, old in the days of the Saxons ; ${ }^{1}$ the mines of Greenhow Hill, ${ }^{1}$ in the parish of Ripon, West Riding, which supplied sheet and pipe lead for the Roman baths and coffins, ${ }^{2}$ at York,

9 A full account of pigs of lead obtained from British mines during the Roman sway in Britain, will be found appended to this memoir. It will be remarked that they belong to early imperial times.

1 See the account of Swaledale, and of the lead-mines near Muker and Reeth in "Rivers, Mountains, and Sea-coast of Yorkshire," by Professor Phillips, p. 52 .

2 Notices of the leaden coffins found at York are given in the Rev. C. Wellbeloved's Eburacum, p. 112. Several other 
as well as tribute to the imperial treasury; the mines of Middleton and Youlgreave (Aldgroove), in Derbyshire, from which the Lutudæ sent not only lead, but 'exargentate' (that is to say refined) lead from which the silver had been removed, use to this day the pig of the same weight of $1 \frac{1}{2}$ cwt., of similar shape, and similar mark to that of eighteen hundred years' antiquity. ${ }^{3}$ And, just as at the present day, the countryman whose galloway is tired, drops the leaden load by the way side, for another day's work, so in the days of Rome, the Brigantian lead was thrown down from the tired caballus by the side of the ancient mining road, on Matlock Moor in Derbyshire, and Dacre Pasture in Yorkshire.

This fact of the discovery of the Roman lead, not at the mines, but at a distance of some miles from them on a track leading towards a Roman or rather a pre-Roman station, is of much importance in Archaeology. For thus we arrive, in the first place, at the conviction of the existence of very ancient mining roads not of Roman work, nor probably of Roman but of earlier date, leading toward Cataractonium, Isurium, Eburacum, Mancunium, Derventio, or rather to the Brigantian towns or centres of trade, on which the Romans, following their wont in Africa, Spain, and Gaul, fixed their attention and established their war-camps and their colonies. The politic lords of the world broke up no national industry, set no legionaries to supplant the native miners; but stationing a few cohorts on the ancient roads, in or close to the mining district, as at Hope and Bainbridge, to control a rude population, received regularly the fruits of the industry which they might direct, but did not personally share. Viewed in this light, how complete appears the grasp of the Roman treasury on the mining fields of Britain! The Fossway from the Ocrynian Promontory crosses the Mendip Hills, the road

remarkable examples of the Roman age, found near London and in other parts of England, are described in this Journal, vol. x. p. 225 ; vol. xii. pp. $77,78,195$. See also Mr. Wright's, "The Celt, the Roman, and the Saxon," p. 308.

3 The modern pig is near one-sixteenth of a fodder, or $176 \frac{1}{4} \mathrm{lb}$. Three Roman pigs found near Matlock, in 1777, 1783, and 1787 , weigh $173 \mathrm{lb}$., $127 \mathrm{lb}$., and $83 \mathrm{lb}$., these being as $1, \frac{s}{4}$, and $\frac{1}{2}$ of the modern pig. In Saxon times the plaustrala, or cart-load, consisted of ten tabulax, or pigs; since it is recorded in Domesday that the manors of Bakewell, Ashford, and Hope, in Derbyshire, paid (inter alia) "v. plaustratas plumbi de 1. tabulis." Pegge observes that Fudur, both in Saxon and German, signifies a cart-load (Archaeologia, vol. v. p. 374). Ray, in his North country Words, explains fother as a certain weight, eight pigs, or $16001 \mathrm{~b}$. The fother appears to vary in different counties from $19 \frac{1}{2} \mathrm{cwt}$ to $24 \mathrm{cwt}$. 
from Mancunium to Bremetonacum traverses the calamine district of Bowland, the road from Derventio or Tutbury to Mancunium runs along the west of the great Derbyshire field, and the legionary path from Carlisle to York goes right across the metalliferous country of Yorkshire and Durham.

We may even ask, with some confidence, whether the line of the Hadrian Wall, which cuts off from the North all the richest mines of the Derwent, the Allen, and the Tyne, but abandons the mossy dales of bleak Northumbria, was not drawn with especial reference to the mining wealth of the districts.

May we not regard, as a confirmation of all that has been advanced touching the antiquity of our mining processes, the fact of the existence to this day, though impaired by recent Acts of Parliament, of peculiar rights and privileges in the mining districts? These rights are sometimes guaranteed by, and appear to emanate from royal charters, as in the stannaries of Cornwall and Devon ; but they are probably of far earlier date, and have merely been confirmed as old customs by King John and his successors. In Mendip, the Forest of Dean, and Derbyshire, the miner's' rights were preserved by royal officers, but the rights themselves transcend all history and tradition. To sink a pit or drive a level in any field ; to cover the rich herbage with barren ore-stuff; to cut a way to the public road; to divert, employ, and waste the running waters ; and to do all this without consent of owner, and without compensation being so much as asked by lord or villein, landlord or tenant, implies in Derbyshire a settlement of mining rights long anterior to Domesday Book, the charters of Repton Abbey, ${ }^{4}$ the neighing of the Saxon

4 The mines in the neighbourhood of Wirksworth were wrought early in the eighth century; at which period that district belonged to the nunnery at Repton, over which Eadburga, the daughter of Adulph, king of the East Angles, presided as Abbess. She bequeathed to St. Gutblae, who had received as it is reported, the tonsure and clerical habits at Repton, a coffis of lead, and a linen cloth to enwrap his corpse. They were transported to Gutblac's oratory in the swampy island of Croylaud, Lincolnshire. "Reverentissima Egburg A bbatissa, Aldulfi Regis filia, per legatum suppliciter ro- gante, Gutblacus Sarcofagum plumbeum et in eo linteum ad involvendum se post obitum suscepit." Orderici Vitalis Eccl. Hist., lib. iv. p. 530. On Guthlac's death in 715 , his corpse shrouded in the "syndone" sent by Eadburga, was deposited in this leaden sarcophagus. - Compare Leland, Coll. vol. ii. p. 590 ; Itin. vol. iv. p. 140. This lead was doubtless obtained from the possessions of the old Saxon religious establishments at Repton, part of which were the mines near Wirkswortl. In the year 835 , Kenewara, then Abbess of Repton, granted to Humbert, the Alderman 
horse, and the flight of the Roman eagle. In connection with all that has been mentioned before, the furnaces, the roads, the restricted vend, the foreign trade, they seem to me to indicate a people who came with many inventions from the metalliferous East to the metalliferous West, before the Athenians drew silver from Laurion, or the Carthaginians from Iberia.

To these ancient, these Semitic mining processes, we have added perhaps steel instruments, and certainly explosive agents; the ore-hearth still remains, but it is generally yielding to the reverberatory furnace; silver is no longer obtained by oxidation of some thousand times its weight of lead; steam blows our furnace-fires, rolls and pipes our metals, and flies with iron wings on roads more solid than the Appian way. The world of George Stephenson is much different from that of Julius Agricola; but some features of the past remain to connect the earliest with the latest aspect of our country ; and among these the least altered, and the most instructive, appear to be the mineral products and the mining processes. If by these we judge the great Brigantian tribes which surrounded Isurium, that great centre of Roman occupation in the West Riding, they must be placed far higher on the scale of civilisation than the place usually accorded by the Saxon to the Celt.

I presume to think, indeed, that without full attention to the mining history of Britain, as indicated by fragments in classic authors, and illustrated by processes not yet extinct, the opinion which may be formed of the ancient British people would be altogether conjectural, derogatory, and erroneous.

her estate called Wircesworth, on condition of rendering annually, as a rent, to Archbishop Ceolnoth and his successors, lead to the value of 300 shillings, for the use of Christ's Church, Canterbury. Script. Decem, col. 2222 ; Somner, Ant. Cant., p. 38, App. On the destruction of Repton Abbey by the Danes, in 874 , it is probable that the lead mines became the property of the Crown. As such they are mentioned in Domesday Book. Under Werchesvorde we find the entry, "ibi sunt ij. plumbarix," which is supposed by Mr. Pegge to signify lead mines. See bis memoir on a Pig of Lead found in Derbyshire, Archæologia, vol. v. p. 374 ; and Glover's Derbyshire, vol. i. p. 73.

This Memoir was originally given in the Proceedings of the Yorkshire Philosophical Society for March, 1848, and is here reproduced with the author's corrections, and the following supplement. 